\title{
The Romantic Myth of Jean-Gaspard Deburau
}

Jean-Gaspard Deburau is renowned for being the greatest and most influential mime artist before Marcel Marceau (who himself was influenced by Deburau) in the twentieth century. ${ }^{1}$ Such was his standing in the 1830s and 1840s that a veritable myth was created around him which has persisted ever since. By 'myth', I mean two different but related phenomena. Some of the ways in which contemporaries thought and wrote about Deburau were probably not factually accurate. Others were embellishments or exaggerations. In neither case was the intention to deceive; on the contrary, the purpose seems to have been to use Deburau to express a vision of art and society, to give form and significance to what certain writers thought was important. The contemporary discourse on Deburau was, to some extent, a constructed discourse intended to turn him into a symbol of certain Romantic ideals. I use 'myth' in the same sense that Louisa E. Jones uses it to refer to an analogous and contemporaneous phenomenon created around Watteau's painting Pierrot, formerly known as 'Gilles': 'an image complex, and complex image, which satisfies and shapes at various levels of consciousness the dreams and frustrations of several generations of artists and writers'. ${ }^{2}$

In order to understand the myth of Deburau and his theatre, Le Théâtre des Funambules, I shall first summarise the qualities which contemporaries so admired in his Pierrot role, and then consider some of them in the light of four Romantic topoï: nostalgia for the Commedia dell'arte, the image of the working-class artist, of the Bohemian artist, and of the sick artist. This will challenge contemporary and modern assumptions about Deburau, but it will not undermine his artistic significance. Firstly, because the mythologisation does not concern all aspects of the man and his work, and secondly, because the very fact that he was the object of a Romantic myth suggests how outstanding his art was for leading writers and critics of the age.

\section{The contemporary reception of Deburau}

A mime artist succeeds or fails depending on the quality of his physical expressiveness. It is a notable aspect of contemporary comment on Deburau that the clarity and meaningfulness of his mime was never called into question during thirty years of a relatively high-profile career. This is rare in the history of early modern and modern mime; comprehensibility is usually the first criticism levelled at performers. Romantic ballet is a telling example, since it is contemporary with Deburau, as well as being a form of theatre dance in which mime was a more or less essential component. Even those ballet dancers renowned as mimes were sometimes criticised for a lack of clarity. ${ }^{3}$ Not only did Deburau remain untouched by this kind of criticism, but he was repeatedly and consistently praised for the subtle, evocative power of his body language. According to Champfleury, he spoke volumes with a mere blink. ${ }^{4}$ Sand

\footnotetext{
${ }^{1}$ Marcel Marceau acknowledges the influence of the nineteenth-century Pierrot in general, and of Deburau in particular, in Marcel Marceau, 'Pierrot de Montmartre', Arts, 19 June 1952.

${ }^{2}$ Louisa E. Jones, Pierrot-Watteau; A Nineteenth-century Myth (Tübingen: Gunter Narr Verlag, and Paris:

Editions Jean-Michel Place, 1984), p. 8.

${ }^{3}$ See for example La Presse, 6 April 1846, p. 1 for Gautier's criticism of Grisi in Paquita, or Le Coureur des spectacles, 21 Feb. 1848, p. 1 for criticism of Petipa in Griseldis.

${ }^{4}$ Champfleury, Souvenirs et portraits de jeunesse (Paris: Dentu, 1872), p. 64.
} 
reports that the audience 'listened' to him as if he were speaking, as if every little nuance of body language were articulating a meaning as complex as could be expressed in words. She, like many others, felt entranced by the expressiveness of his silence. ${ }^{5}$ Gautier thought it Shakespearian. In his well-known review of Le Marrrchand d'habit, entitled 'Shakspeare [sic] aux Funambules', he compares the scene in which Deburau steps on the head of the ghost who taunts him through the floorboards to the moment in Shakespeare's play when Hamlet retorts with an air of casual audacity to the ghost 'Well said, old mole!' (Act I, Scene 5). Even Shakespeare, claims Gautier, could not have found a better equivalent in mute action for Hamlet's words. ${ }^{6}$ Gautier's review itself could be seen as a curious example of how inspiring Deburau was. It is, in fact, not a review at all, despite what many later scholars have assumed, since it was published at least six weeks before the performance on the stage of the Thêatre des Funambules. If it is a 'review' of anything, it is of the action played out solely in Gautier's mind. Perhaps the director of the Théâtre des Funambules, Cot d'Ordan, read it in La Revue de Paris and decided to stage it, since the censor's copy is signed by him. ${ }^{7}$

Deburau's expressive muteness was all the more remarkable for being a choice, not an obligation. Unlike renowned early modern and modern performers who mimed because the theatre licensing laws did not allow them to speak (the mimes of the eighteenth century 'foires' are a good example), Deburau must have made a personal decision. Licensing laws were relaxed after the July 1830 Revolution. Deburau could have done what every other contemporary actor did and perform speaking roles. Uniquely, however, he continued to mime and never spoke. ${ }^{8}$ It is a moot point whether his uniqueness contributed to his appeal, or whether he appealed despite the sudden and drastic decline in the popularity of mime after $1830 .{ }^{9}$ His legacy is nevertheless clear in at least one respect: the prevalent modern assumption that mime is mute derives from the aesthetic choice he made. It did not exist before him.

He also owed his contemporary fame to the Pierrot role he played for most of his career, from 1816 until his death in $1846 .{ }^{10}$ His contemporaries were impressed that he had succeeded in doing what all great Commedia performers had done for three centuries: he had modified an existing role, Pierrot, so that it was both recognizable but also new and surprising. His stage persona was a new and brilliant permutation of an old and revered role. According to Sand, he did this by raising the tone of the traditional Pierrot:

\footnotetext{
${ }^{5}$ George Sand, 'Deburau', in Le Constitutionnel, 8 Feb. 1846, pp. 2-3 (3).

${ }^{6}$ Gautier, 'Shakspeare [sic] aux Funambules', Revue de Paris, Series 4, Vol. 9 (4 Sept. 1842), pp. 60-66. (63).

${ }^{7}$ The censor only gave permission to perform a pantomime with this title on the 17 October 1742 . See Le

Marrrchand d'Habit, Paris, Archives nationales de France, $\mathrm{F}^{18} 1087$. For further discussion, see Robert Storey, Pierrots on the stage of desire: nineteenth-century French literary artists and the comic pantomime (Princeton, N.J: Princeton University Press, 1985), p. 40.

${ }^{8}$ According to Péricaud, there was a single exception to Deburau's silence: in Le Marchand de Salade, he says 'achetez salade!' in a hoarse whisper. See Louis Péricaud, Le Théâtre des Funambules, ses mimes, ses acteurs (Paris: Sapin, 1897), p. 92. Janin also cites a single, but different exception, which may mean there were two occasions when Deburau broke his characteristic silence. See Janin, Journal des Débats, 19 Sept. 1868, p. 2.

${ }^{9}$ Mime theatre dominated the repertoire of the Théâtre des Funambules until August 1830 when vaudeville suddenly became the most frequent kind of performance. This is clear from a study of the extant plot synopses now kept in the Archives nationales de France and in the library of the Société des Auteurs et Compositeurs Dramatiques, Paris, and it is also clear in Péricaud, Le Théâtre des Funambules (1897).

${ }^{10}$ It is in 1816 that the plot synopses sent to the censor begin to specify in the cast lists that Deburau plays Pierrot. See for example Arlequin libérateur du genie blanc, authored by M. Martial, archived in the library of the Société des auteurs et compositeurs dramatiques, Paris.
} 
Il n'est point vorace, mais friand. Au lieu d'être débauché, il est galant [...] Il n'est point fourbe, mais railleur et plaisant, il n'est pas colère non plus, il est équitable, et quand il administre ses admirables coups de pied, c'est avec l'impartialité d'un juge éclairé et la grâce d'un marquis. Il est essentiellement gentilhomme jusqu'au bout de ses longues manches, et il n'est point une chiquenaude qu'il ne détache poliment et avec des façons de cour. ${ }^{11}$

Sand's description suggests a Pierrot who has become more reflective, who has learnt to moderate the worst of his characteristic excesses until they have almost become virtues, a Pierrot who has matured. Banville describes another new and surprising feature of Deburau's Pierrot. He is a Commedia 'zani' who has learnt to withdraw from the action which he would hitherto have been expected to lead (along with other zani such as Harlequin). Rather than actively prompting and stirring events, he often appeared detached form the action: 'Déburau [sic] vit dans une action dramatique, et la traverse incessamment, mais sans jamais s'y mêler d'une façon sérieuse.' ${ }^{\prime 2}$

It was not only the novel features of Deburau's Pierrot which struck his contemporaries, however, but the fact that they produced contrasts, paradoxes, even grotesque combinations. Gautier summed him up with a series of oxymorons: 'la crédulité sceptique, la servilité dédaigneuse, l'insouciance occupée, l'activité fainéante, et tous ces étonnants contrastes' ${ }^{13}$ In the plot synopses sent to the censor, he often plays the part of a mischievous rogue saved from the consequences of his actions by his naïve, childish virtues. Symbolic of this are his white costume and white face makeup which remain immaculate whatever trouble he causes for himself or for others. Appropriately, he is called in one plot synopsis, 'ce mal blanchi', and Banville thought his costume was 'd'une blancheur épique'. ${ }^{14}$

The success of Deburau's Pierrot might be measured by the legacy it has left us. Although the role had been popular since it had been created in the second half of the seventeenth century, it was never defined as mute until Deburau reinterpreted it. It had only been mute if and when theatre licensing laws obliged it to be so. Deburau's version of the role would appear to have been so influential that his idiosyncratic choice of muteness stuck. Thus, not only did Deburau redefine mime as a mute art, but he also redefined Pierrot as a mute role.

There was nevertheless more to Deburau than Pierrot. He was also good at playing character parts simultaneously with his Pierrot role. That is to say, he was self-evidently Pierrot (because by all accounts he kept his typical white face makeup and often his black skullcap, not to mention aspects of his typical behaviour), but he added a further layer to his performance by acting a character part, such as 'cordonnier' or 'marchand de salade'. This we can partly judge from the frequent comments by spectators such as Banville who remarks on his ability to swagger as a fishmonger balancing a basket of fish on his head, on the appetising way he

\footnotetext{
${ }^{11}$ Sand, 'Deburau', in Le Constitutionnel, 8 Feb. 1846, pp. 2-3 (3).

12 Banville, 'Les Petits Théâtres de Paris', in Musée des familles; lectures du soir, 84 vols (Paris, 1833-1900), Vol. 13 (1845-6), pp. 237-247 (238).

13 Théophile Gautier in La Presse, 31 Aug. 1841, p. 1. See also Auguste Jal, Salon de 1831. Ebauches critiques (Paris: Dénain, 1831), pp. 178-9.

${ }^{14}$ Deburau's character is referred to as 'ce mal blanchi' by another character in Les Epreuves, grande pantomime-arlequinade-féerie en treize tableaux, Archives nationales de France, $\mathrm{F}^{18} 1083$. For Théodore de Banville's comment, see his 'Deburau et les Funambules', in L'Ame de Paris, nouveaux souvenirs (Paris: Charpentier, 1890), pp. 11-45 (38).
} 
prepared cabbage soup as a cook, on the convincing way he adopted the gestures and manner of a cobbler, on the dazed, naïve, studied incompetence he cultivated as an army conscript. It seemed to him that Deburau was 'un peintre des moeurs, un caricaturiste' performing something akin to a Balzacian 'comédie humaine' of social types and behaviour. ${ }^{15}$ Although in principle it was not new for a Pierrot or Commedia role to play a character part, Deburau did it more often than past Pierrots did. ${ }^{16}$ The consequence was that, although makeup and behaviour kept Pierrot alive in the spectator's consciousness, social realism inevitably loomed larger than it had done before. Although the Pierrot role was integral to his performance, it was the character which was prominent in spectators' minds.

The particular 'comédie humaine' he performed was working-class. This is evident from even a cursory glance at the cast lists in the plot synopses sent to the censor, and it is a topos of contemporary critical reaction. One of his fellow actors, Vautier, evidently thought this to be an essential part of his stage persona, since he produced a lithograph to mark the death of Deburau in 1846, depicting him in a dozen of his most famous roles, all of which are working class (see illustration). ${ }^{17}$ The working class image persisted after his death, too. Shortly before the Funambules theatre was demolished in 1862 to make way for Haussmann's remodelled Paris, it staged a commemorative performance entitled 'Mémoires de Pierrot' in which Deburau's son, Charles, played twenty-two Pierrot characters, most of them his father's invention. Of these, only three were not working class (the marquis, the lawyer, and Watteau), and these were not Deburau père's invention anyway. ${ }^{18}$

The social realism of Deburau's roles must have contributed to the widespread view of him as a working-class hero of the arts, or as one of his greatest admirer's put it: 'Gilles, c'est le peuple'. Presumably, what Janin meant by this expression was that Deburau's Gilles or Pierrot role (the terminology was almost synonymous in this period) was not so much the representation of a single individual, not even the concentration of a single social type, rather he was the essence of a whole stratum of society, 'le peuple'. ${ }^{19}$ In the socio-political context of the 1830s and 1840s, Janin's expression is an arresting one indeed. He seems to mean that Deburau was a condensation of the values that, for example, Michelet expressed in his 1846 work Le Peuple: work, suffering, political consciousness, and true spirit which is the only firm foundation for a new society. ${ }^{20}$

\footnotetext{
15 Banville, 'Les Petits Théâtres de Paris', (1845-6), p. 39.

16 The evidence for Deburau lies partly in illustrations such as the one by Vautier shown here, in which he is more often than not shown in a costume other than the typical Pierrot costume. It lies, also, in the cast lists in the censor's copy of the plot synopses. Sometimes, Deburau is listed simply as performing 'Pierrot' who, in turn, plays a typical Commedia part such as 'valet' or 'domestique'. More often than not, however, Deburau performs 'Pierrot' who in turn performs a character role such as those cited by Banville above. This is not nearly as common in early French Pierrots. See collections such as Gherardi's Supplément du Théâtre italien, ou Nouveau Recueil des comédies et scènes françoises qui ont été joüées sur le Théâtre italien par les comédiens du Roi de l'Hôtel de Bourgogne à Paris, 4 vols (Amsterdam: Adrian Braakman, 1697), or Le Nouveau Théâtre italien. Ou Recueil général des comédies représentées par les Comédiens italiens ordinaires du roi, 10 vols (Paris: Briasson, 1753).

${ }^{17}$ Although the working-class nature of all the parts is not entirely clear from every costume in the illustration, the plot synopses submitted to the censor (archived in Paris at the Archives nationales de France, $\mathrm{F}^{18}$, and in the library of the Société des artistes et compositeurs dramatiques) make this evident.

${ }^{18}$ For a list of roles, see Péricaud, Le Théâtre des Funambules (1897), p. 493. The last performance at the Théâtre des Funambules took place on the 14 July 1862.

${ }^{19}$ Jules Janin, Journal des débats, 1 Nov. 1830, p. 3.

${ }^{20}$ See for example Janin, Journal des débats, 1 Nov. 1830, p. 3.
} 
Spectators even commented that his mute language of mime was a translation of popular 'argot' or slang, so that, for example, he would mime the slang expression 'je l'ai eu à l' œil', meaning 'I stole this'. ${ }^{21}$ If his manner was working class during his lifetime, so it was even in death. He died of a common working-class condition, probably pulmonary tuberculosis ('phtisie'), and at his funeral in the Montmartre cemetery, there was a sea of mourners in blue overalls. $^{22}$

It is hard to find any dissenting voices to the praised heaped upon Deburau, either among his contemporaries or in more recent times. This is probably because the praise was partly merited. A significant argument in his favour is the legacy he left; not only the principle that mime and Pierrot should be mute, but also a family of mime artists in more ways than one. His son, Charles, took on the mantle of Pierrot shortly after his death in 1846, appealing to many because of the similarity of his style to his father's, and becoming a celebrated performer in his own right. He taught the next generation of well-known mimes, including Louis Rouffe, who in turn taught the last in the line of the 'Deburau school', Séverin. It was in reaction to the likes of Séverin that the seminal twentieth-century mime teacher, Etienne Decroux, began a profound transformation in the practice and theory of mime. ${ }^{23}$ Decroux taught Marcel Marceau who, much to Decroux's dismay, adopted some features of the 'old' mime and stated his admiration for Deburau. Thus, Deburau propelled the art of mime forward in the nineteenth century, was indirectly a stimulus for radical change in the twentieth century, while remaining a point of reference for modern mime artists. For such a legacy to exist, there must be at least partly true that he was virtuoso mime artist.

\section{Nostalgia for the Commedia dell'arte}

There is, though, another side to the Deburau phenomenon which has never been taken into account: the capacity for nineteenth-century Romantic writers to cultivate a myth. Romanticism is at least in part a movement of activists militating for socio-cultural change. In a number of respects, Deburau proved a very useful symbol for their ideas, and it is the purpose of what follows to assess Deburau's iconic status in the light of this.

It is odd that almost all contemporary discussion of Deburau places him squarely in the 300-year old tradition of the Commedia and he is almost never considered in the context of specifically French traditions. Pierrot's origins are, in fact, more complicated than this. Scholarly opinion differs on this subject, but one can plausibly argue that he was spawned in the second half of the seventeenth century from a process of mutual influence and reciprocal inspiration when a troupe of Italian players shared the Hôtel de Bourgogne in Paris with Molière's company. The Italians' performance of the Dom Juan myth in 1658 is thought to have encouraged Molière to produce his own famous version in 1665, which itself led the Italians to stage a sort of sequel. In adapting the myth to the French context, Molière introduced a certain 'Pierrot' character, so named either because it was a close translation of the Italian 'Pedrolino', or because it was already a typical French stage name for a slow-witted peasant character, or for both reasons. When, in 1673, the Italians produced their 'sequel' or medley of

\footnotetext{
${ }^{21}$ See Le Journal des beaux-arts, no. 11 (21 Oct. 1840), p. 167. More generally, see La Gazzette des Tribunaux, May 1840, reproduced in Péricaud, Le Théâtre des Funambules (1897), p. 156-7.

${ }^{22}$ See La France théâtrale, 21 June 1846, p. 2, and Le Mercure des théâtres, 21 June 1846, p. 1.

${ }^{23}$ Thomas Leabhart, Franc Chamberlain (eds), The Decroux Sourcebook (Abingdon UK: Routledge, 2008 ), p. 4.
} 
scenes from their play and from Molière's version, they kept the French name 'Pierrot', but attributed to him some of Pedrolino's characteristics. ${ }^{24}$ From this point on, Pierrot appeared regularly in Parisian Commedia productions, until the Italian players were expelled from France in 1697. Neither they nor any other Commedia company used the Pierrot role in their native Italy (perhaps because their existing Pedrolino role sufficed). It was in France during the following century that he developed, first at the foires theatres, then at the Théatre-italien when a new company of Italian players were invited back to France after Louis XIV's death. In addition to the mixed French-Italian background of Pierrot, the situation is complicated by a close relative appearing at the very end of the seventeenth century who was even more of a French creation: 'Gilles'. ${ }^{25}$

Seventeenth and eighteenth-century audiences were aware of the French-ness of Pierrot and Gilles, but it is not often mentioned by the time Deburau performs. The origins of the role are complex and uncertain, but the critical attention afforded to Deburau was so enormous that it is surprising that only one source was considered: the Commedia dell-arte. Commentators are more interested in seeing Deburau as a continuation, even a revival of the Commedia than the next step in an established French tradition. Maurice Sand's judgment is typical of the widespread contemporary opinion: 'la pantomime avec Deburau fut alors tout ce qui nous resta de l'ancienne comédie italienne'. He seems to have regarded the Commedia as a sort of universal theatre with branches almost everywhere. He classifies the English 'clown', for example, as a 'Pierrot' character, and the German 'Hanswurst' as a Pulcinella. He, like most of his contemporaries, never seems to ask himself where influence stops and difference begins.

Perhaps it is a fairly characteristic Romantic nostalgia for the past that led Deburau's contemporaries to associate him so exclusively with the Commedia dell'arte rather than more recent, French traditions. It makes one wonder whether we should take at face value the praise he received for his variation on the Pierrot role. The almost grotesque contrasts of character they so admired, for example, may be comparable to similar contrasts we find in the Pierrots of foire plays by Lesage, Fuzelier and Dorneval a hundred years before Deburau. ${ }^{26}$ The particular mix of intelligence and crudity that Deburau cultivated was comparable to the way 'Gilles' was sometimes played. ${ }^{27}$

\section{The Working-Class Artist}

Deburau's working-class image should be questioned on two counts. The first is purely material: was his income working-class? The answer has to be no, at least for the second half of his career when he was most famous. The first extant contract between Deburau and the Thêâtre des Funambules, covering the years 1828-1831, specifies that he was paid a total weekly wage of 45 Francs (which included 10 francs for looking after the theatre's props). ${ }^{28}$

\footnotetext{
${ }^{24}$ For this theory of Pierrot's origins, see Robert Storey, Pierrot: A Critical History of a Mask (Princeton N.J.: Princeton University Press, 1978), p.17-18.

${ }^{25}$ See Storey, Pierrot (1978), p. 76.

${ }^{26}$ See Storey, Pierrot (1978), p. 53.

${ }^{27}$ See for example Gilles in Léandre Fiacre; parade, in Théâtre des Boulevards, ou Recueil de Parades (A Mahon [sic]: De l'Imprimerie de Gilles Langlois [sic], 1751), Vol. 1, pp. 1-22.

${ }^{28}$ Deburau's first extant contract ran from Easter 1828 to Easter 1831. It is archived in Paris, Musée Carnavalet, Cabinet des Arts Graphiques. It has been widely reproduced; see for example Péricaud, Le Théâtre des
} 
With his next contract, his wages went up to 52 francs (again, including 10 francs for managing the props). ${ }^{29}$ His last contract, running from 1836 to a few months after his death in 1846 marked a considerable change in his fortunes, since not only were his wages increased to 70 Francs, but he was awarded a bonus of 1500 francs/year. ${ }^{30}$ So for the last decade of his life, his yearly income from the Théâtre des Funambules was 5140 Francs, excluding his earnings from the first nights of 'grandes pantomimes' (when he was entitled to half the profits after performance costs were deducted), and from the right to stage benefit performances. His annual income during this period was nearly twenty times the annual rent he paid for his two-bedroom flat a short distance from the Théâtre des Funambules (109 Quai de Valmy, 260 Francs/year). ${ }^{31}$

His income was far higher than that of the contemporary working-class. Georges Duveau estimates that there were four groups of Parisian workers: 'le groupe malheureux' earning less than 2.50 Francs/day, 'le groupe normal' earning 2.50-3.20 Francs/day, 'le groupe heureux' earning between 3.20 and 4 Francs/day, and finally 'le groupe privilègié' earning more than 4 Francs/day. ${ }^{32}$ In these terms, even Deburau's first extant contract of 1828-31 provided him with a 'privileged' income. His last contract, running for ten years until his death, paid him fourteen Francs/day (assuming, not entirely unrealistically, that he worked, or was available to work every day of the year), or more than triple a 'privileged' income. Despite this, the prevailing public image of Deburau was (and still is) a working-class one, or as Nerval almost put it: he was a star who never thought of asking for a pay rise. ${ }^{33}$

Of course, a high income does not necessarily exclude one from 'le peuple', if one defines 'le peuple' as a matter of where one's heart is. This is how Michelet understood the term in his book Le Peuple, and one of Deburau's aristocratic admirers, George Sand, famously thought of herself in these terms. ${ }^{34}$ If one's circle of friends is anything to go by in this respect, then Deburau remained true to his working-class roots, since the 'ligue paternelle' appointed after his death to provide paternal guidance to his two children was made up of 'des relations habituelles d'amitié' who were a 'doreur de porcelaine', a 'passementier', and one other person whose profession is not specified. ${ }^{35}$ This being so, however, one wonders why no one made a

Funambules (1897), p. 56, or Jules Janin, Deburau. Histoire du Théâtre à quatre sous, pour faire suite à L'Histoire du Théâtre-Français, 2 vols in 1 (1832; Paris: Librairie de Charles Gosselin, 1833), Vol. 2, p.6.

29 The second extant contract ran from Easter 1830 to Easter 1837, and can be consulted in Paris at the Bibliothèque nationale de France, Département des Arts du spectacle.

${ }^{30}$ His last contract is not extant, but is cited at length in the sollicitor's calculation of his assets after his death. See 'Inventaire après décès: Deburau, Jean-Gaspard. Valmy (quai de), no. 109, 4 juillet 1846', in Minutes et répertoires du notaire Alphonse Zacharie Leroux, Paris, Archives nationales de France, shelfmark $\mathrm{MC} / \mathrm{RE} / \mathrm{XLIX} / 1327$. These documents also reveal that some time before his death, Deburau had signed a further contract to run ten years until 1856.

${ }^{31}$ See 'Inventaire après décès: Deburau, Jean-Gaspard. Valmy (quai de), no. 109, 4 juillet 1846', Paris, Archives nationales de France, shelfmark MC/RE/XLIX/1327.

${ }^{32}$ Georges Duveau, La Vie ouvrière en France sous le Second Empire (Paris: Gallimard, 1946), p. 304. See also Olivier Marchand and Claude Thélot, Le Travail en France, 1800-2000 (Paris: Nathan, 1997), who estimate the average working-class yearly salary for 1836 to be 547 Francs (p. 241).

${ }^{33}$ I am assuming that we ought to read Nerval ironically when he writes that 'malgré tant de gloire qu'on lui a faite, je n'ai pas appris qu'il ait demandé cent mille francs d'appointements à son directeur'. See his article in L'Artist, 12 May 1844, republished in Nerval, Gérard de, Euvres complètes. Eds Jean Guillaume and Claude Pichois. 3 vols. Paris: Gallimard, "Bibliothèque de la Pléiade", 1984-1993, Vol. 1, p. 799-801 (800).

${ }^{34}$ Sand, Correspondance, 26 vols (Paris: Garnier, 1964-1987), Vol. 6, p. 327.

${ }^{35}$ See 'Inventaire après décès: Deburau, Jean-Gaspard. Valmy (quai de), no. 109, 4 juillet 1846', Paris, Archives nationales de France, shelfmark MC/RE/XLIX/1327. 
case for Deburau as, specifically, the well-healed man of the people, in the way that others like Michelet and Sand did for themselves. The only image ever presented to readers of newspapers or books on the subject is an uncomplicated one, that he was working class.

The reason for this discrepancy is most probably that we are dealing, again, with the construction of a Romantic archetype rather than a realistic depicture of the man. It is not an isolated phenomenon. Similar tendencies are evident in the way contemporary writers wrote about a star of Romantic theatre, the actress known as Rachel who rose from illiterate street singer to become one of the most admired performers at the Thêatre-français. ${ }^{36}$ Dumas turned a similar 'rags-to-stardom' story into fiction in his play Kean, about the English actor Edmund Kean who rose from working-class roots to becoming reputedly the greatest actor in the world. ${ }^{37}$

One should also relate the way Deburau was fêted as a working-class artist to the contemporary phenomenon of the 'ouvriers-poètes', working-class poets promoted by wellknown intellectuals like Sand, Dumas or Hugo. As Sand writes in the preface to the collection of verse by her protégé Charles Poncy's, the year 1840 saw a great flowering of this phenomenon: 'tout à coup, dix, quinze, vingt et trente poètes ouvriers se sont mis à écrire et à chanter sur tous les points de la France'. ${ }^{38}$ She was perhaps thinking of the first anthology of verse of ouvriers-poètes published in 1841 which to a large extent drew its content from poetry appearing in the monthly journal La Ruche populaire, itself founded by working-class writers in $1839 .{ }^{39}$ For certain Romantics, these writers were the realisation of the inevitable progress of art and society: the 1789 revolution gave the common man political freedom, the Romantic revolution would give him artistic freedom to create art in new ways, and both freedoms would enrich society in general. As Dumas put it in the preface he wrote for the baker-turned-poet from Nîmes, Jean Reboul: 'ce peuple, dont tout est sorti depuis cinquante ans, après avoir donné à la France des soldats, des tribuns et des maréchaux, allait donc aussi lui fournir des poètes!'. ${ }^{40}$ In this context, it is not surprising that a consummate working-class performer like Deburau should appeal to intellectuals on a socio-artistic mission. What better candidate was there than an actor who did not perform at a state-sponsored theatre, who did not need bourgeois patrons or intermediaries to sell his art, who in addition was a mime artists and therefore did not even speak the articulated language which had manifestly failed militant Romantics in the 1830 Revolution, and who was a consummate artist, perhaps a genius, into the bargain?

\section{The Bohemian Artist}

\footnotetext{
${ }^{36}$ See, for example, Musset's praise of Rachel in his article 'De la Tragédie. A Propos des débuts de Mademoiselle Rachel', first published on 1 Nov. 1838 in La Revue des deux Mondes, reproduced in Musset, Alfred de, Euvres complètes en prose. Eds Maurice Allem and Paul-Courant. 1 vol. Paris: Gallimard, "Bibliothèque de la Pléiade," 1960, pp. 888-901.

37 Alexandre Dumas, Kean, ou Désordre et génie, first performed in Paris 31 Aug. 1836 at the Théâtre des Variétés, with Frédérick Lemaître in the lead role.

${ }^{38}$ Charles Poncy, Poésies de Charles Poncy, ouvrier maçon de Toulon. Marines - Le Chantier (Paris: au bureau de la Société de l'industrie fraternelle, 1846), preface by George Sand.

${ }^{39}$ Olinde Rodrigues (ed.), Poésies sociales des ouvriers (Paris: Paulin, 1841).

40 Jean Reboul, Poésies, précédées d'une préface par M. Alexandre Dumas, et d'une lettre à l'éditeur, par M. Alphonse de Lamartine (Paris: C. Gosselin, 1836), p. ix.
} 
Allied to his working-class image was the Romanticised poverty of Deburau the Bohemian artist. Decades before the topos of the artist as Bohemian became widespread, Deburau's geographical origins in the central-European Kingdom of Bohemia caused many contemporaries to view him as the prototype of the wandering, adventurous artist who rejects material comforts of bourgeois life in favour of a modest, unpretentious but free-spirited life as an artist. ${ }^{41}$ The critic and novelist Jules Janin wrote a two-volume, highly flattering monograph on Deburau which opens with a detailed account of the performer's background. Although accurate in its basic details, ${ }^{42}$ the style is highly florid, partly because Janin was a Romantic critic seeking to turn literary criticism into an art form in itself, but also because he seems to want to create a certain image of Deburau: the Bohemian artist in spirit as well as in geographic origins. As the writer of an obituary for Deburau later put it: '[Deburau] appartient à la fois, par sa naissance, à la Bohème de la géographie réelle, et par sa destinée à cette Bohème de la géographie fantastique'. ${ }^{43}$

In his account, Janin emphasises the hardship endured by the Deburau family as they travelled across Europe, as well as the way they managed to laugh off adversity as only 'des comédiens insouciants' from Bohemia could. ${ }^{44}$ He devotes significant attention to Deburau's lack of theatrical talent in the early years when he was obliged to perform as an acrobat rather than the Pierrot he later became. He is 'le pauvre sauteur' who was so incompetent that he would regularly injure himself and the audience would often boo him off stage. Yet Deburau is also the 'pauvre grand homme', because he has hidden talents which in those early years no one, not even he himself, had seen. ${ }^{45}$ Janin frequently combines descriptions of the poor, suffering, itinerant actor with praise for the unrecognised genius of the expressive artist, as if to explain the artist as outcast by reference to his unique nature. Deburau is reported to have commented that the portrait did not resemble him. ${ }^{46}$

Deburau is, in fact, not the only contemporary actor whom Janin treated in this way. Discussing Marie Dorval and Frédérick Lemaitre in their early careers, before they became legends of the Romantic stage, Janin calls them 'nos admirables bohémiens' ${ }^{47}$ Dorval, like Deburau, was from a modest background, and both she and Lemaitre began their careers in Boulevard theatres similar in character to Deburau's Théâtre des Funambules. Janin seems intent on bringing to light a certain aspect of the artist which later became a major topos of Romantic writing. He creates an image of the natural genius who, from humble beginnings, rose to stardom, but instead of becoming absorbed into bourgeois society, remained detached

\footnotetext{
${ }^{41}$ There has recently been a rise in interest in the Bohemian artist. See particularly the anthology edited by JeanDidier and Françoise Cestor, Les Bohèmes, 1840-1870: Ecrivains, journalists, artistes (Seyssel: Champ Vallon, 2012), and the catalogue of the exhibition held in Paris at the Grand Palais from 26 Sept. 2012 to 12 Jan. 2013, Bohèmes: Le Roman de la liberté, ed. Florence Hudowicz (Paris: RMN-Grand Palais, 2012).

${ }^{42}$ See the biography by Tristan Rémy, Jean-Gaspard Deburau (Paris: L'Arche, 1954).

${ }^{43}$ Paul de Saint-Victor, 'Mort d'un artiste et de son art', in La Semaine, July 1846, newspaper cutting in an unpaginated collection of cuttings, Paris, Bibliothèque des arts et spectacles, Rondel 11577.

44 Janin, Deburau, (1833), Vol. 1, p. 28.

45 Janin, Deburau (1833), Vol. 1, p. 34.

${ }^{46}$ George Sand reports that Deburau told her this. See Le Constitutionel, 8 Feb. 1846, p.2. Ambs-Dalès also claims that Janin exaggerated parts of his biography; see J.-B. Ambs-Dalès, Petite Histoire d'un grand acteur. Histoire de Deburau (Paris: Au Théâtre des Funambules, 1832), p. 1.

${ }^{47}$ Janin, Histoire de la littérature dramatique, 6 vols (Paris: Michel-Lévy frères, 1853-1858), Vol. 4, p. 304.
} 
from it, like a travelling 'Bohemian' who gets from society what he can without ever actually integrating himself into it.

\section{The Sick artist}

For most of his career, no one commented on Deburau's health. Subsequently, however, there were a number of retrospective views. The most common in the immediate days and weeks after his death was that he came to an untimely end due to head injuries sustained a few weeks earlier in a stage accident, falling through a trap door which should have been closed. ${ }^{48}$ Later accounts of his death, however, attribute it either to pulmonary tuberculosis ('phtisie') or chronic asthma. Both the immediate and the later explanations could have some substance to them, but again, it is the style in which they are recounted which reveals something of the Romantic outlook contemporary writers had on Deburau.

The best example is from the pen of the novelist and writer of pantomime scenarios, Champfleury, writing in 1859, thirteen years after Deburau's death. According to him, Deburau had been suffering from asthma for five years before his death; 'il toussait à rendre les poumons' ${ }^{49}$ Near the end of his life, the doctor prescribed a long period of rest, but Deburau insisted on continuing to perform; 'il songeait à son public'. On stage, he did not show any symptoms of his illness, but 'la terrible maladie attendait dans les coulisses, sous le quinquet huileux, et posait sa griffe sur la poitrine du mime à chacune de ses sorties.' He was obliged to rest for three weeks, after which he returned to perform what was to be his last pantomime, Les Noces d'Arlequin. The audience, especially the 'titis' in the gods, were ecstatic to see him return to the stage. Dressed in his characteristic white costume, but also holding the wedding bouquet necessary to the plot, Deburau made a gesture thank the audience for their welcome: '[il] mit simplement la main sur le coeur, au-dessous de son bouquet de fiancé. Une larme coula sur la farine de son visage. Une vraie larme au théâtre est si rare!'. During the performance, Deburau refrained from doing his characteristic eccentric dance, provoking one spectator to call out for 'une Chahut' (the Cancan), and many others to respond 'non! non!', because they realised that Deburau was too ill. A few days later, Champfleury remarks, Deburau died.

We have no sure way of knowing how much of Champfleury's account is accurate, but it reads like a retrospective creation based on later Pierrot images, not those that were fashioned in Deburau's lifetime. The macabre image of personified illness waiting in the wings to embrace the comic Pierrot as he leaves the stage is reminiscent of the pantomimes that Champfleury wrote for the Funambules in the years after Deburau's death (e.g. Pierrot valet de la Mort, Pierrot pendu, Madame Polichinelle ou Les Souffrances d'une âme en peine), ${ }^{50}$ reminiscent, in fact, of the general trend after Deburau's death towards the macabre in art. The image of Pierrot's sad, white, tear-stained face is also one that is very suggestive of a later, more sentimental Pierrot created by Deburau's son, Charles. It has since become a visual cliché, but Deburau père was not noted in the slightest for his sentimentality. As his biographer has

\footnotetext{
48 Journal des debats, 19 June 1846, p2.

49 The italics are original. This quotation and those following from Champfleury's account of Deburau's last performance are from his Souvenirs des Funambules (Paris: Michel Lévy Frères, 1859), pp. 11-12.

${ }^{50}$ For a catalogue of pantomimes performed at the Théâtre des Funambules (and at other Parisian theatres), see the 'Handlist of Pantomime Scenarios' in Robert Storey, Pierrots on the Stage of Desire. Nineteenth-Century French Literary Artists and the Comic Pantomime (Princeton: Princeton University Press, 1985), pp. 317-333.
} 
put it, the 'sel forain' of his style was quite unlike the 'sucre vanillé' of later Pierrots. ${ }^{51}$ And lastly, Champfleury paints Deburau as a martyr to his art, when in fact he may have felt obliged to perform simply because his contract did not allow for sick pay. One clause of the contract reads: 'En cas de maladie, le directeur se réserve le droit de suspendre les appointements de l'artiste jusqu'au jour de sa rentrée'. ${ }^{52}$ If Janin is to be believed, then this clause was relatively harsh, since actors in other theatres were paid when sickness prevented them performing, as long as they had not contributed to their illness by some sort of negligence. ${ }^{53}$

Even during Deburau's lifetime, Janin contributed to the image of the suffering artist in his biography by recounting how Deburau supposedly took his employer to court to claim damages for working conditions so damp that mushrooms were apparently growing in his dressing room (a large example of which was presented as evidence in court). ${ }^{54}$ This story spread after Janin first recounted it, despite the fact that it was probably false. ${ }^{55}$ In any case, there is evidence that conditions for actors at the Thêatre des Funambules were, in fact, decent. In correspondence with the Parisian authorities, the director of the Funambules in the 1820s and 1830s, Nicolas-Michel Bertrand, insists that actors dressing rooms were 'des pièces carrelées et plafonées'. ${ }^{56}$ A floor plan produced in 1850 in the course of what one would nowadays call a 'health and safety' inspection shows that the actors' changing rooms were on the first floor, not in the basement where there would be more chance of damp and fungal infestation. ${ }^{57}$

Perhaps Champfleury and Janin painted this picture of Deburau because, like many other contemporary writers, they thought it important to draw attention to the sick artist. Hugo wrote at length about the budding young Swiss poet Ymbert Galloix who came to Paris in 1827 to seek his literary fortune, and died the following year of pulmonary tuberculosis (the possible cause, also, of Deburau's death). ${ }^{58}$ The sculptor David d'Angers made great (and in the end successful) efforts to find a publisher for the dying poet Aloysius Bertrand. ${ }^{59}$ Although not sick, Baudelaire's 'Vieux Saltimbanque' is a similar and striking example of the emblematic status accorded to the spent artist, consumed by a life of aesthetic principle in an unforgiving

\footnotetext{
${ }^{51}$ Rémy, Jean-Gaspard Deburau (1954), p. 218.

${ }^{52}$ Clause 5 of both his 1828 and 1830 contracts (see footnotes 28 and 29).

${ }^{53}$ Janin, Deburau (1833), Vol. 2, pp. 32-33.

${ }^{54}$ Janin, Deburau (1833), Vol. 2, pp. 19-31.

${ }^{55}$ Janin's story is repeated, for example, in L'Independent, 6 July 1834, p. 1, but it is contradicted by Ambs-Dalès, Petite Histoire d'un grand acteur (1832), p. 2, who cites the pages of the court circulars to show that the case concerned a different actor at a different theatre.

${ }^{56}$ Letter from Nicolas-Michel Bertrand to the Préfet de Police, March 1819, in response to a report made earlier the same month by 'le Commandant des Sapeurs-pompiers, l'Architecte commissaire de la petite Voirie et le Commissaire de police', recommending the closure of the Théâtre des Funambules and Mme Saqui's Théâtre des acrobates on the grounds that they were a fire hazard. See 'Petit spectacle des Funambules, anciennes affaires 3', in 'Théâtre des Funambules 1813-1879', Paris, Archives nationales de France, F ${ }^{21} 1154$.

${ }^{57}$ Letter from the Prefet de Police to the Ministre de l'Intérieur (3 April 1850), concerning installation of fire safety equipment; see 'Grand'garde de sapeurs-pompiers. Réclamations' in 'Funambules, direction Billion, 1845 1856', Paris, Archives nationales de France, $\mathrm{F}^{21} 1154$.

58 Victor Hugo, 'Ymbert Galloix', in L'Europe littéraire, 1 Dec. 1833, reproduced in Victor Hugo, Euvres Complètes, eds Reynaud, Seebacher, and Rosa (Paris: Robert Lafont, 2002- ), the volume 'Critique', pp. 191207.

59 Marvin Richards, Without Rhyme or Reason: Gaspard de la Nuit and the Dialectic of the Prose Poem (Lewisburg: Bucknell University Press; London: Associated University Presses, 1998), p. 125.
} 
world. ${ }^{60}$ In this context, Champfleury and Janin may have wanted their readers to think of Deburau as another artist who suffered, as all true artists must, according to Romantic principles. It is not clear, however, how historically accurate their description is.

What emerges from this study of the two sides to Deburau's contemporary reception is that he appears to have been a consummate artist, but also a Romantic icon, mythologised by his contemporaries. The myth has been passed down to successive generations of scholars and practitioners of mime without it being questioned. This phenomenon sheds light on a key period in the history of the Pierrot role, and of mime in general. After the eighteenth century, Pierrot was thought by many to be fading away, along with the Commedia dell'arte with which he was, rightly or wrongly, associated. The impetus that Deburau gave him not only revived interest, but was the beginning of a fascination with Pierrot on the part of artists of all kinds for the rest of the nineteenth century and indeed beyond. The mythologisation I have described should be viewed in this context: something about Deburau must have been special in order for his version of Pierrot to be the first in a long line of evocative Pierrot images.

\section{Conclusion:}

No modern scholars have done much to shed light on the 'myth' of Deburau, although some have obliquely referred to it, such as Martinez: it's the assumption of her book on mime in the second half of the 19c that mime did not die with Deburau in 1846, because brilliant as he may have been, he wasn't the be-all and end-all of the art. Maybe it's her interest in post-Deburau mime which leads her to see through the myth.

\footnotetext{
${ }^{60}$ Baudelaire, Charles, 'Le Vieux Saltimbanque', in Le Spleen de Paris (petits poèmes en prose). In Baudelaire, Charles, Euvres complètes, ed. Claude Pichois. 2 vols. Paris: Gallimard, "Bibliothèque de la Pléiade", 1975-76, Vol. 1, p. 295-7.
} 